\title{
Obituaries
}

Obituaries should be submitted by email to Laura Pacey at I.pacey@nature.com.

All submitted obituaries should be 350 words maximum in length (apart from obituaries for past presidents of the BDA where the length should be $700-800$ words).

Content of the obituary is down to the individual author, and the approval of the family should be given for the obituary prior

to submission to the $B D J$.

\section{JOHN DEREK HAWORTH}

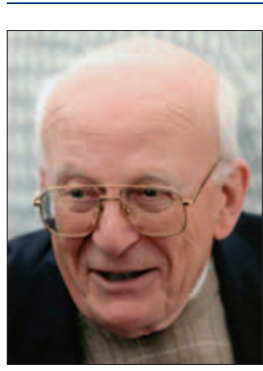

John Derek

Haworth, known

to all his many

friends as 'Bloggy'

died 25 June 2012.

His nickname,

the origins of which

are shrouded in mystery, was given

to him as a pupil at Epsom College during WW2. He took the pre-medical exam while still at school and entered Guy's Hospital Dental School in 1945.

At Guy's, Bloggy relished the practical aspects of the course. During these five-years he was awarded the very prestigious Newland Pedley Prize in 1949 for extensive restorative treatment. He qualified LDS RCS in 1950 and was appointed House Surgeon at Guy's for three months before starting his National Service in the RAF Dental Branch.

On completion of his National Service, he set up practice in Burgh Heath in Surrey and worked there in the NHS for some years. His practice became so busy that he changed to private practice. In October 1955 he was appointed as a part-time demonstrator in the Conservation Department at Guy's for three sessions a week. Some years later he decided to retire from general practice when he was appointed to a full-time post in the same department. He retired from Guy's in 1990. Bloggy was an extremely popular and enthusiastic member of staff, always ready to help students and his colleagues, be it with their dentistry or their golf swing. Bloggy was very inventive, seen in the many modifications he made to his dental equipment. Who can forget his technique for casting a gold inlay, after he had retired, using half a King Edward potato?
For many years he was a member of the Guy's Students' Golf Club and a regular participant at the annual staff/ student match, as well as a member of Banstead Golf Club and the Royal Cinque Ports at Deal. Many of his colleagues from Guy's and the Golf Club were at the Memorial Service held on 20 July at St Augustine Church, Northbourne Kent.

He married Jill Wardener on 14th February 1953, they had two sons and a daughter, Richard, Anne and Jeremy, to all of whom are extended sympathy in their loss. It is also a loss which is shared by several generations of Guy's dental students, his many professional colleagues and of course the patients who benefitted from his skill as a dentist.

Adrian Harold Redfern (J.) Rowe, Richard Bell Johns

\section{JOHN BURROWS}

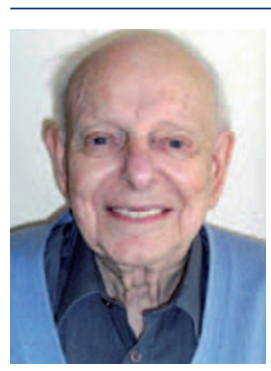

John was born on 24 July 1924. His early life was spent in Folkestone where his father, a Latin scholar, endowed him with a love of classics that was to lead

him to Durham University.

However, the Second World War intervened and John entered the RAF, initially training Tiger Moth pilots in Canada before returning to the UK to fly Lancaster bombers. After hostilities ceased he was moved to Transport Command where he flew Dakotas between India and London.

After leaving the RAF he decided to train as a dentist at the London Hospital. He then started a two-year associate position at a surgery in Ryde, Isle of
Wight, from where he joined a five-man dental partnership in the heart of Tunbridge Wells. He was to remain there for almost 40 years.

John's energy and talents allowed him to combine his partnership in the Tunbridge Wells practice with a part time dental clinic at 83 Harley Street. He also made outstanding contributions as both the chairman of the Dentist and General Society and secretary of the Tunbridge Wells section of the BDA.

Retiring from dentistry at the beginning of the 1990s, the early years of John's retirement were spent with his wife Alison in Tunbridge Wells and at their holiday home in Suffolk. More recently John and Alison moved to Devon to be closer to their family. He died on 29 August 2012 at the age of 88.

John's friend of 60 years and former dental partner, Peter Kershaw, describes an intelligent and caring man; 'having greatly enjoyed working with John on the Isle of Wight, I was delighted that we were able to maintain that relationship over such a long period in Tunbridge Wells. John was the ideal dentist; he combined superb technical skills with an ability to build excellent and long standing relationships with his patients and colleagues. He was always happy to provide thoughtful advice to both partners and staff and the surgery's long term stability and success was a testament to his ability to get on with all those around him. In partnership meetings, his counsel was always invaluable and his contributions to the wider dental community were both highly regarded and hugely appreciated. But more than any of this, John was a wonderful friend.'

Peter Kershaw, John Mew 